\title{
Metformin targets the GTPase Rac1 to inhibit prostate cancer cell migration
}

\author{
Béatrice Dirat ${ }^{1,2}$, Isabelle Ader ${ }^{2}$, Muriel Golzio², Amel Mettouchi ${ }^{1,2}$, Kathiane Laurent ${ }^{1,2}$, Frédéric Larbret ${ }^{2}$, \\ Bernard Malavaud ${ }^{3,2}$, Mireille Cormont ${ }^{1,2}$, Emmanuel Lemichez ${ }^{1,2}$, Jean François Tanti ${ }^{1,2}$, Frédéric Bost ${ }^{1,2^{*}}$ \\ From Metabolism, Diet and Disease 2014: Cancer and metabolism \\ Washington DC, USA. 28-30 May 2014
}

\section{Background}

The anti-diabetic drug metformin has been shown to affect cancer cell metabolism $[1,2]$ and to display antitumoral properties in numerous cancers [3,4], however, its role in the formation of metastases remains poorly documented. Cell migration is a critical step in the progression of prostate cancer to the metastatic state, the lethal form of the disease.

\section{Results}

We show here that metformin reduces the occurrence of metastases in an orthotopic metastatic prostate cancer cell model established in nude mice. As predicted, metformin hampers cell motility in PC3 and DU145 prostate cancer cells and triggers a radical reorganization of the cell cytoskeleton. The small GTPase Rac1 is a master regulator of cytoskeleton organization and cell migration. We report that metformin inhibits Rac1 GTPase activity by interfering with some of its multiple upstream signaling pathways, namely P-Rex1 (a Guanine nucleotide exchange factor and activator of Rac1), cyclic AMP and CXCL12/CXCR4, resulting in decreased migration of prostate cancer cells. Importantly, overexpression of a constitutively active form of Rac1 (Rac1-Q61L or Rac1-V12), or P-Rex1 as well as the inhibition of the adenylate cyclase were able to reverse the anti-migratory effects of metformin.

\section{Conclusion}

Our results establish a novel mechanism of action for metformin through Rac1 and highlight its potential antimetastatic properties in prostate cancer.

\section{Acknowledgement}

This research was supported by The French National Institute for Cancer (INCa) and The foundation ARC.

\section{Authors' details}

${ }^{1}$ INSERM U1065, C3M, Nice, France. ${ }^{2}$ CNRS U5089, IPBS, Toulouse, France.

${ }^{3}$ Rangeuil Hospital, Toulouse, France.

Published: 28 May 2014

\section{References}

1. El-Mir MY, Nogueira V, Fontaine E, Averet N, Rigoulet M, Leverve X: Dimethylbiguanide inhibits cell respiration via an indirect effect targeted on the respiratory chain complex I. J Biol Chem 2000, 275:223-8.

2. Ben Sahra I, Laurent K, Giuliano S, Larbret F, Ponzio G, Gounon P, et al: Targeting cancer cell metabolism: the combination of metformin and 2deoxyglucose induces p53-dependent apoptosis in prostate cancer cells. Cancer Res 2010, 70:2465-75.

3. Ben Sahra I, Laurent K, Loubat A, Giorgetti-Peraldi S, Colosetti P, Auberger P, et al: The antidiabetic drug metformin exerts an antitumoral effect in vitro and in vivo through a decrease of cyclin D1 level. Oncogene 2008, 27:3576-86.

4. Zakikhani M, Dowling R, Fantus IG, Sonenberg N, Pollak M: Metformin is an AMP kinase-dependent growth inhibitor for breast cancer cells. Cancer Res 2006, 66:10269-73.

\section{doi:10.1186/2049-3002-2-S1-024}

Cite this article as: Dirat et al:: Metformin targets the GTPase Rac1 to inhibit prostate cancer cell migration. Cancer \& Metabolism 2014 2(Suppl 1): O24.

Submit your next manuscript to BioMed Central and take full advantage of:

- Convenient online submission

- Thorough peer review

- No space constraints or color figure charges

- Immediate publication on acceptance

- Inclusion in PubMed, CAS, Scopus and Google Scholar

- Research which is freely available for redistribution 